\title{
Economy of Energy during Refrigerating Machine
} Operation

\author{
Aleksandr Vasserman and Aleksey Slyn'ko \\ Odessa National Maritime University, Odessa, Ukraine
}

\begin{abstract}
Idealized cycles of refrigerating machines with adiabatic and isothermal compression of refrigerant vapor were investigated. Energetic characteristics of cycles: specific mass and volume cooling capacity $q_{0}$ and $q_{\mathrm{v}}$, work of compression 1 , refrigerating coefficient of performance $\varepsilon$ and power $\mathrm{N}$ for drive of compressor were compared. These characteristics were calculated for eight refrigerants at temperature of their condensation $30{ }^{\circ} \mathrm{C}$ and temperatures of boiling $-15{ }^{\circ} \mathrm{C}$ and $-30{ }^{\circ} \mathrm{C}$. The calculations show that the use of isothermal compression of refrigerant vapor ensures economy of energy during refrigerating machine operation.
\end{abstract}

Key words: Vapor compressor refrigerating machines, adiabatic and isothermal compression of refrigerant, energetic characteristics of cycles.

\section{Introduction}

Refrigerating machines are widely used both for the transportation and storage of provisions and liquefied gases and comfort technical conditioning of air. Vapor compressor refrigerating machines are most often used with adiabatic compression of the refrigerant vapor.

The theoretical considerations and our calculations $[1,2]$ have shown that isothermal compression of refrigerant is energetically more effective than adiabatic compression. In this paper the economy of energy at isothermal compression using an example of eight widely used refrigerants is investigated.

\section{Idealized Cycles of Refrigerating Machines}

In Fig. 1, the cycle with adiabatic compression of refrigerant (further A-cycle) is shown on the temperature-entropy diagram. At this cycle the restricted regenerative heat exchange between liquid and vapor is used. Owing to such heat exchange the specific mass cooling capacity $q_{0}$ increases, but the work of compression increases also. Therefore, the

Corresponding author: Aleksandr Vasserman, professor, doctor of technical sciences, research fields: thermophysical properties of substances and refrigerating machines. refrigerating coefficient of performance may increase, decrease or not change depending on the properties of the refrigerants.

The cycle with isothermal compression of refrigerant (further I-cycle) is shown in Fig. 2. At this cycle limiting regeneration is used. Due to such regeneration the vapor is heated to the temperature of condensation. Then it is compressed isothermally to the state of saturation. Therefore, in Fig. 2 the point 2 corresponding to the state of vapor after compression coincides with the point 3 , which corresponds to the state of saturated vapor.

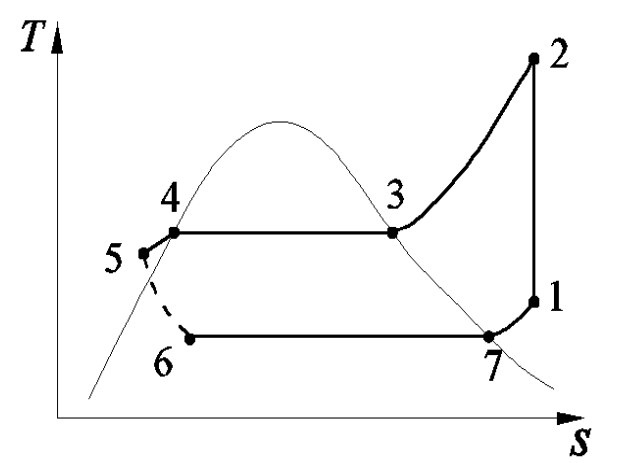

Fig. 1 Cycle with adiabatic compression of refrigerant. 1-2 - adiabatic compression of vapor, 2-3 - cooling of vapor, 3-4-condensation of vapor, 4-5-restricted regenerative cooling of liquid, 5-6-throttling of refrigerant, 6-7-boiling of refrigerant, 7-1-restricted regenerative heating of vapor. 


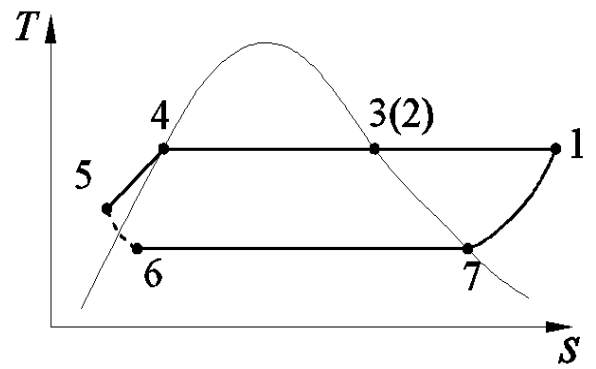

Fig. 2 Cycle with isothermal compression of refrigerant. 1-3(2) - isothermal compression of vapor, 3(2)-4-condensation of vapor, 4-5-limiting regenerative cooling of liquid, 5-6-throttling of refrigerant, 6-7-boiling of refrigerant, 7-1-limiting regenerative heating of vapor.

To realize isothermal compression, it is necessary to use a compressor which is cooled intensively. Creation of such compressors is quite possible. To decrease fresh water expense, the water after compressor may be cooled in saltpan.

\section{Comparison of Two Investigated Cycles}

To compare the A-cycle and I-cycle, the energetic characteristics of two cycles were calculated. Specific mass and volume cooling capacity $q_{0}$ and $q_{v}$, specific work of compression of vapor $l$, refrigerating coefficient of performance $\varepsilon$ and power $N$ for drive of compressor were calculated by formulae:

$$
\begin{gathered}
q_{0}=h_{1}-h_{7}, \\
q_{v}=q_{0} / v_{1}, \\
l=h_{2}-h_{1}, \\
\varepsilon=q_{0} / l, \\
N=l m,
\end{gathered}
$$

where, $h, \quad \mathrm{~kJ} \cdot \mathrm{kg}^{-1}$ are values of enthalpy in corresponding points of cycles, $\mathrm{m}, \mathrm{kg} \cdot \mathrm{s}^{-1}$, is the mass expense of refrigerant.

The temperature of condensation of refrigerants was taken to be $30{ }^{\circ} \mathrm{C}$, the temperatures of boiling $-15{ }^{\circ} \mathrm{C}$ and $-30{ }^{\circ} \mathrm{C}$ and temperature of liquid after restricted regenerative heat exchange at A-cycle $25{ }^{\circ} \mathrm{C}$. To calculate power $N$ the full cooling capacity of refrigerating machine was taken to be $100 \mathrm{kWt}$.

The calculations were carried out for eight refrigerants indicated below. For these refrigerants the temperature of boiling at atmospheric pressure changes from $-24.32{ }^{\circ} \mathrm{C}$ for R152a to $-51.70{ }^{\circ} \mathrm{C}$ for $\mathrm{R} 32$. The necessary values of thermodynamic properties of refrigerants were taken from the well-known REFPROP information system [3]. To calculate real values of specific work of compression $l$, coefficient of performance $\varepsilon$ and power $N$, the methods described in the monograph $[4,5]$ were used.

In Tables 1 and 2 the calculated energetic characteristics for A-cycle at temperatures of refrigerant boiling $-15{ }^{\circ} \mathrm{C}$ and $-30{ }^{\circ} \mathrm{C}$ are presented. In Tables 3 and 4 the results of comparison of corresponding energetic characteristics for investigated cycles at mentioned temperatures of refrigerant boiling are presented.

From Tables 3 and 4 one can see that the limiting regeneration at the I-cycle leads to significant increase of the specific mass cooling capacity $q_{0}$ in comparison with A-cycle, where restricted regeneration is realized. This increase is noticeably greater at lower temperature or refrigerant boiling and for different refrigerants is equal approximately from $7 \%$ to $32 \%$ at $t_{\text {boil }}=-15^{\circ} \mathrm{C}$ and from $10 \%$ to $47 \%$ at $t_{\text {boil }}=-30{ }^{\circ} \mathrm{C}$.

The values of specific volume cooling capacity $q_{v}$ for I-cycle in some cases are lower than for A-cycle. In these cases for I-cycles in comparison with A-cycle the specific volume of refrigerant after regeneration

Table 1 Energetic characteristics of A-cycle at temperature of refrigerant boiling $-15^{\circ} \mathrm{C}$.

\begin{tabular}{lllllllll}
\hline Refr. & $q_{0}, \mathrm{~kJ} \cdot \mathrm{kg}^{-1}$ & $q_{v}, \mathrm{~kJ} \cdot \mathrm{m}^{-3}$ & $l, \mathrm{~kJ} \cdot \mathrm{kg}^{-1}$ & $l_{\text {real }}, \mathrm{kJ} \cdot \mathrm{kg}^{-1}$ & $\varepsilon$ & $\varepsilon_{\text {real }}$ & $N, \mathrm{kWt}$ & $N_{\text {real }} \mathrm{kWt}$ \\
\hline $152 \mathrm{a}$ & 253 & 1,175 & 54.0 & 92.0 & 4.76 & 2.75 & 21.0 & 36.4 \\
$134 \mathrm{a}$ & 155 & 1,284 & 33.5 & 57.1 & 4.63 & 2.72 & 21.6 & 36.8 \\
717 & 1,127 & 2,117 & 242 & 390 & 4.65 & 2.89 & 21.5 & 34.6 \\
290 & 293 & 1,827 & 64.0 & 102 & 4.58 & 2.87 & 21.8 & 34.9 \\
$407 \mathrm{C}$ & 165 & 1,732 & 44.1 & 69.4 & 3.74 & 2.38 & 26.7 & 42.1 \\
125 & 92.9 & 2,254 & 22.7 & 35.0 & 4.09 & 2.65 & 24.5 & 37.7 \\
\hline
\end{tabular}


Table 2 Energetic characteristics of A-cycle at temperature of refrigerant boiling $-30{ }^{\circ} \mathrm{C}$.

\begin{tabular}{lllllllll}
\hline Refr. & $q_{0}, \mathrm{~kJ} \cdot \mathrm{kg}^{-1}$ & $q_{v}, \mathrm{~kJ} \cdot \mathrm{m}^{-3}$ & $l, \mathrm{~kJ} \cdot \mathrm{kg}^{-1}$ & $l_{\text {real }}, \mathrm{kJ} \cdot \mathrm{kg}^{-1}$ & $\varepsilon$ & $\varepsilon_{\text {real }}$ & $N, \mathrm{kWt}$ & $N_{\text {real }} \mathrm{kWt}$ \\
\hline 717 & 1,106 & 1,093 & 361 & 662 & 3.06 & 1.67 & 32.6 & 59.8 \\
290 & 275 & 1,024 & 91.1 & 168 & 3.02 & 1.63 & 33.1 & 61.1 \\
$407 \mathrm{C}$ & 157 & 932 & 59.5 & 107 & 2.63 & 1.47 & 38.0 & 68.2 \\
125 & 84.8 & 1,182 & 32.8 & 58.5 & 2.58 & 1.45 & 38.7 & 68.9 \\
$410 \mathrm{~A}$ & 170 & 1,700 & 58.9 & 98.0 & 2.89 & 1.74 & 34.6 & 57.6 \\
32 & 201 & 1,885 & 88.7 & 153 & 2.94 & 1.70 & 34.0 & 58.6 \\
\hline
\end{tabular}

Table 3 Deviations $\delta, \%$ of characteristics of I-cycle from values for A-cycle at temperature of refrigerant boiling $-15{ }^{\circ} \mathrm{C}$.

\begin{tabular}{lllllllll}
\hline Refr. & $\delta q_{0}$ & $\delta q_{v}$ & $\delta l$ & $\delta l_{\text {real }}$ & $\delta \varepsilon$ & $\delta \varepsilon_{\text {real }}$ & $\delta N$ & $\delta N_{\text {real }}$ \\
\hline $152 \mathrm{a}$ & 15 & -1 & 2 & -11 & 13 & 29 & -11 & -22 \\
$134 \mathrm{a}$ & 20 & 3 & 5 & -10 & 14 & 32 & -12 & -25 \\
717 & 7 & -7 & -8 & -20 & 17 & 34 & -14 & -25 \\
290 & 21 & 4 & 5 & -10 & 15 & 34 & -13 & -25 \\
$407 \mathrm{C}$ & 19 & 6 & -11 & -22 & 33 & 53 & -25 & -35 \\
125 & 32 & 12 & 8 & -8 & 23 & 44 & -18 & -30 \\
\hline
\end{tabular}

Table 4 Deviations ö, \% of characteristics of I-cycle from values for A-cycle at temperature of refrigerant boiling $-30{ }^{\circ} \mathrm{C}$.

\begin{tabular}{lllllllll}
\hline Refr. & $\Delta q_{0}$ & $\delta q_{v}$ & $\delta l$ & $\delta l_{\text {real }}$ & $\delta \varepsilon$ & $\delta \varepsilon_{\text {real }}$ & $\delta N$ & $\delta N_{\text {real }}$ \\
\hline 717 & 10 & 33 & -11 & -30 & 23 & 58 & -19 & -37 \\
290 & 30 & 6 & 7 & -14 & 21 & 51 & -18 & -34 \\
$407 \mathrm{C}$ & 39 & 13 & -3 & -18 & 44 & 70 & -30 & -41 \\
125 & 47 & 18 & 10 & -12 & 34 & 68 & -25 & -40 \\
$410 \mathrm{~A}$ & 25 & 1 & 2 & -15 & 23 & 47 & -19 & -32 \\
32 & 17 & -5 & -5 & -23 & 23 & 52 & -19 & -34 \\
\hline
\end{tabular}

increases greater than the specific mass cooling capacity. For R717 the value of $q_{v}$ decreases by about $7 \%$ at $t_{\text {boil }}=-15{ }^{\circ} \mathrm{C}$ and for $\mathrm{R} 32$ by $5 \%$ at $t_{\text {boil }}=-30{ }^{\circ} \mathrm{C}$, and it demands an increase of the compressor volume.

The value of the theoretical specific work of compression of vapor $l$ at I-cycle for some refrigerants is greater than at A-cycle owing to different initial and final parameters of the mentioned process at these cycles. The values of specific real work $l_{\text {real }}$ for I-cycle are smaller in all cases because the effective coefficient of efficiency for it is greater than for A-cycle.

The values of theoretical and real refrigerating coefficient of performance $\varepsilon$ and $\varepsilon_{\text {real }}$ for I-cycle are in all cases greater than for A-cycle. The maximum increase of these values takes place for R407C. For this refrigerant they reach $33 \%$ and $53 \%$ at $t_{\text {boil }}=$ $-15{ }^{\circ} \mathrm{C}$ and $44 \%$ and $70 \%$ at $t_{\text {boil }}=-30{ }^{\circ} \mathrm{C}$. The minimum increase of $\varepsilon$ and $\varepsilon_{\text {real }}$ is observed for R152a at $t_{\text {boil }}=-15{ }^{\circ} \mathrm{C}(13 \%$ and $29 \%)$ and for $\mathrm{R} 290$ and
R410A at $t_{\text {boil }}=-30{ }^{\circ} \mathrm{C}\left(21 \%\right.$ for $\varepsilon$ and $47 \%$ for $\varepsilon_{\text {real }}$ correspondingly).

For $\mathrm{R} 407 \mathrm{C}$ the maximum decrease of theoretical and real power for drive of compressor $N$ and $N_{\text {real }}$ takes place. This decrease is equal to $25 \%$ and $35 \%$ at $t_{\text {boil }}=-15{ }^{\circ} \mathrm{C}$ and $30 \%$ and $41 \%$ at $t_{\text {boil }}=-30{ }^{\circ} \mathrm{C}$. The similar decrease of values $N_{\text {real }}$ takes place for R125: $30 \%$ at $t_{\text {boil }}=-15{ }^{\circ} \mathrm{C}$ and $40 \%$ at $t_{\text {boil }}=-30{ }^{\circ} \mathrm{C}$. The minimum increase of $N$ and $N_{\text {real }}$ is observed for $\mathrm{R} 152 \mathrm{a}$ at $t_{\mathrm{boil}}=-15{ }^{\circ} \mathrm{C}(11 \%$ and $22 \%)$ and for $\mathrm{R} 290$ and $\mathrm{R} 410 \mathrm{~A}$ at $\mathrm{t}_{\text {boil }}=-30{ }^{\circ} \mathrm{C}(18 \%$ for $N$ and $32 \%$ for $N_{\text {real }}$ correspondingly).

The accomplished analysis may help to choose the most suitable refrigerant for refrigerating machine operating with isothermal compression of vapor. Such analysis can be realized for different temperatures of refrigerant condensation and boiling. For this aim the energetic characteristics of A-cycle and I-cycle must be calculated. 


\section{Conclusions}

The results of our calculations for wide range of refrigerants show the advantages of cycle with isothermal compression of refrigerant vapor as compared to the cycle with adiabatic compression. These advantages are a significant increase of refrigerating coefficient of performance and corresponding decrease of power for the compressor drive. They take place not only for idealized cycle, but for real cycle too. Therefore, it is expedient to create effective compressors with isothermal compression of refrigerants. Owing to the economy of electrical energy during refrigerating machine operation, the economic effect of operation of new machines will be greater than expenditures on their creation.

\section{References}

[1] Vasserman, A. A., Lavrenchenko, G. K., and Slyn'ko, A.
G. 2014. "Osobennosti idealizirovannykh tsyklov parokompressornykh kholodil'nykh mashin (Peculiarities of the Idealized Cycles of Vapor Compressor Refrigerating Machines).” Tekhnicheskie gazy (Industrial Gases) 6: 30-6. (in Russian)

[2] Vasserman, A. A., and Slyn'ko, A. G. 2016. "Sposib zdiysnennya teoretychnogo tsyklu parokompresornykh kholodylnykh mashin (Method of Realization of Theoretical Cycle of Vapor Compressor Refrigerating Machines)". Ukrainian patent on invention No.110869. Bulletin "Promyslova vlasnist" (Industrial Property), 4.

[3] Lemmon, E. W., Huber, M. L., and McLinden, M. O. 2007. "NIST Reference Fluid Thermodynamic and Transport Properties-REFPROP, Version 8.0." Gaithersburg, 51.

[4] Zagoruyko, V. A., and Golikov, A. A. 2000. "Sudovye kholodyl'nye ustanovki (Ships' refrigerating plants)". Kiev, publ. house "Naukova dumka (Scientific thought)", 607. (in Russian)

[5] Zakharov, Yu. V. 1994. "Sudovye ustanovki konditsionirovaniya vozdukha I kholodil'nye mashiny". Sankt Peterburg, publ. house "Sudostroenie (Ships Building)”, 504. (in Russian) 